\title{
Growth, Phenology and Seed Yield of Fodder Maize in Relation to Different Planting Methods and Nitrogen Levels
}

\author{
Rupinder Kaur Jassal, J.S. Kang*, Harmeet Singh and Thakar Singh \\ Department of Agronomy, Punjab Agricultural University, Ludhiana-141 004, Punjab, India \\ *Corresponding author
}

A B S T R A C T

\begin{tabular}{l} 
K e y w o r d s \\
Bed planting, \\
Conventional \\
tillage, Fodder \\
maize, Nitrogen \\
and Zero tillage. \\
\hline Article Info \\
Accepted: \\
15 March 2017 \\
Available Online: \\
10 April 2017
\end{tabular}

An experiment was conducted at Punjab Agricultural University, Ludhiana to find out the appropriate planting method and optimum nitrogen level for enhancing the seed yield of fodder maize (Zea mays L.) variety J-1006. The experiment was conducted in strip plot design with three sowing methods viz. zero tillage (ZT), conventional tillage (CT) and bed planting (BP) in vertical strips and four nitrogen levels $(0,100,125$ and $150 \mathrm{~kg} N / \mathrm{ha})$ in horizontal strips. Pheonological parameters like days taken to $50 \%$ tasseling, days taken to $50 \%$ silking and days taken to physiological maturity were statistically at par with different planting methods except days taken to dough stage. Growth indices viz., Crop growth rate and Relative growth rate were significantly affected with planting methods except Net Assimilation Rate. Nitrogen application of $150 \mathrm{~kg} \mathrm{~N} /$ ha produced the significantly higher seed yield than 0,100 and $125 \mathrm{~kg} \mathrm{~N} / \mathrm{ha}$. This was due to the higher number of cobs (1.2), cob girth (3.6), number of grains per cob (274.8) which were comparably higher in bed planted crop with $150 \mathrm{~kg} \mathrm{~N} / \mathrm{ha}$ as compared to other treatments. Quality parameters viz., nitrogen content in grains and stover and protein content in grains were not significantly affected with different planting but bed planted crop showed increased content of nitrogen in grains $(1.6 \%)$ and stover $(1.4 \%)$ and protein content in grains $(10 \%)$ as compared to zero tillage and conventional tillage methods. Different nitrogen levels showed increased nitrogen content in grains $(1.8 \%)$, nitrogen content in stover $(1.7 \%)$ and protein content in grains $(11 \%)$ at $5 \%$ significance level.

\section{Introduction}

In India area under fodder crops is only $8.4 \mathrm{~m}$ ha which is static since last two decades. At present, the country faces a net deficit of $61.1 \%$ green fodder, $21.9 \%$ dry crop residue and $64 \%$ feeds (Chaudhary et al., 2012). Not only fodder production in the country is sufficient to meet the requirement and also the forage offered to animals is mostly of poor quality. Maize (Zea mays L.) is an ideal fodder crop possessing quick growing and high yielding ability during summer season and can be fed to the cattle at any stage of growth, as there is no problem of hydrocyanic acid poisoning to cattle. Seed availability is one of the major constraints in increasing production of fodder crops. So there is needed to be improving the seed production by adopting suitable planting methods and with proper nitrogen management. Proper planting method can play a key role in maximum utilization of applied fertilizer and available water resources. Method of sowing is the major factor which is responsible for soil moisture storage, judicious use of fertilizer, 
water, good crop stand and better crop growth. Simes et al., (1998) suggested that pre-plant tillage may be necessary to optimize grain yield and reported lower continuous corn yields with no tillage compared with conventional tillage. The conventional flat planting is the common practice of raising crops in India but this practice has resulted in the degradation and inefficient use of basic resources and various inputs. Raised bed cultivation has traditionally been associated with water management as it reduces the impact of excess water in high production irrigated systems and also helps in saving of about $15-20 \%$ of irrigation water as reported by Sayre (2003).

Nitrogen is an essential element required for successful plant growth. Although inorganic nitrogen compounds (i.e., $\mathrm{NH}_{4}^{+}, \mathrm{NO}_{2}^{-}$, and $\mathrm{NO}_{3}{ }^{-}$) account for less than $5 \%$ of the total nitrogen in soil, they are the main forms of the element absorbed by most plants. Inorganic and organic fertilizers are applied to maintain the nutritional condition of different cropping systems (Brady et al., 2014). Nitrogen requirement of maize varies with soil type, climate, genotype and management practices. However, due to environmental pollution, high nitrate concentrations accumulate in the edible parts of these leafy vegetables, particularly if excessive nitrogen fertilizer has been applied. Consuming these crops can cause health problems; thus, developing a suitable strategy for the agricultural application of nitrogen fertilizer is important (Cheng et al., 2014). So, efficient $\mathrm{N}$ management is important in minimizing agricultural contribution to nitrate pollution of ground water and optimizing profit for corn producers. Hirel et al., (2001) reported that higher nitrogen dose results in greater biomass production, increased photosynthesis rates, increased capacity for sucrose metabolism and consequently higher yield. At the same time, the crop should not suffer from deficiency of this nutrient. Therefore, it becomes necessary to determine its optimum dose, which will meet the requirements of crop and ensure maximum returns.

Therefore, with the above facts the present study was carried out to determine the effect of zero tillage, conventional planting and bed planting on the growth and seed yield of maize fodder and to find out the optimum levels of nitrogen for enhancing growth and productivity of fodder maize.

\section{Materials and Methods}

A field experiment was carried out at the Students' Research Farm, Department of Agronomy, Punjab Agricultural University, Ludhiana $\left(36^{\circ} 54^{\prime}\right.$ North latitude and $75^{\circ} 48^{\prime}$ East longitudes; 247 meters above mean sea level) in kharif season of 2012. The mean weekly maximum temperature ranged between $31^{\circ} \mathrm{C}$ to $40.8^{\circ} \mathrm{C}$ and minimum temperature ranged between $20.7^{\circ} \mathrm{C}$ to $29.3^{\circ} \mathrm{C}$. Total rainfall received during crop season was $61.2 \mathrm{~mm}$. The meteorological data for Ludhiana during crop season (June 2012September 2012) are given in table 1 (Source: Meteorological data recorded at PAU meteorological observatory, Ludhiana).

The treatments were replicated three times in strip plot design. The treatments consisted of three planting methods in vertical strips viz. zero tillage (ZT), conventional tillage (CT) and bed planting (BP) and four nitrogen $(\mathrm{N})$ $(0,100,125$ and $150 \mathrm{~kg} \mathrm{~N} / \mathrm{ha})$ levels in horizontal strip. The soil of experimental field was sandy loam in texture and normal in $\mathrm{pH}$ (7.3), EC (0.18 mmhos $\left.\mathrm{cm}^{-1}\right)$ and organic carbon $(0.57 \%)$, low in available $\mathrm{N}(125 \mathrm{~kg}$ $\mathrm{N} / \mathrm{ha})$ and medium in $\mathrm{P}\left(12.3 \mathrm{~kg} \mathrm{P}_{2} \mathrm{O}_{5} / \mathrm{ha}\right)$ and $\mathrm{K}$ (115.0 $\left.\mathrm{kg} \mathrm{K}_{2} \mathrm{O} / \mathrm{ha}\right)$. Nitrogen was applied in the form of urea in three splits as per treatments. One third of $\mathrm{N}$ was applied at sowing and other one third at knee high stage 
near the plant base and remaining one third at pre tasseling stage. The row-to-row spacing was kept at $50 \mathrm{~cm}$ and plant-to-plant spacing of $20 \mathrm{~cm}$ was maintained. The crop husbandry practices followed were as per recommended package of practices given by PAU. Five plants were randomly selected from the each plot and tagged for various observations like number of leaves, various phenological stages and yield attributes. Crop growth rate, relative growth rate and net assimilation rate were calculated by using standard formulas (Hunt 1989).

Formulas of growth indices used are as follows

\section{a) Crop growth rate}

Crop growth rate is an index of production efficiency of land area in producing plant biomass. Crop growth rate is expressed as $\mathrm{g}$ $\mathrm{m}^{-2}$ day $^{-1}$ and was calculated by using formula given by Hunt (1989).

$\mathrm{CGR}=\mathrm{w}_{2}-\mathrm{w}_{1} / \mathrm{t}_{2}-\mathrm{t}_{1} \longrightarrow(1)$

Where, $\mathrm{w}_{2}$ and $\mathrm{w}_{1}$ are dry matter $(\mathrm{g})$ at time $\mathrm{t}_{1}$ and $\mathrm{t}_{2}$

\section{b) Relative growth rate}

Relative growth rate expresses growth in terms of rate of increase in size per unit time. Relative growth rate is expressed as $\mathrm{g} \mathrm{g}^{-1}$ day

${ }^{1}$ and was calculated by using formula given by Hunt (1989).

$\mathrm{RGR}=\ln \mathrm{w}_{2}-\ln \mathrm{w}_{1} / \mathrm{t}_{2}-\mathrm{t}_{1} \longrightarrow(2)$

Where, $\mathrm{w}_{2}$ and $\mathrm{w}_{1}$ are dry matter $(\mathrm{g})$ at time $\mathrm{t}_{1}$ and $\mathrm{t}_{2}$

\section{c) Net assimilation rate}

The net assimilation rate is the index of production efficiency of plant leaf calculated in relation to total leaf area. Net assimilation rate is expressed as $\mathrm{g} \mathrm{g}^{-1} \mathrm{day}^{-1}$ and was calculated by using formula given by Hunt (1989).

Equation no. 3

$\mathrm{NAR}=\frac{\ln \mathrm{LA}_{2}-\ln \mathrm{LA}_{1}}{\mathrm{LA}_{2}-\mathrm{LA}_{1}} \times \frac{\mathrm{w}_{2}-\mathrm{w}_{1}}{\mathrm{t}_{2}-\mathrm{t}_{1}}$

Where, $\mathrm{LA}_{1}, \mathrm{LA}_{2}$ are the leaf area index and $\mathrm{w}_{2}, \mathrm{w}_{1}$ are dry matter $(\mathrm{g})$ at time $\mathrm{t}_{1}$ and $\mathrm{t}_{2}$. Days taken to $50 \%$ tasseling and silking were recorded from the date of sowing till $50 \%$ plants in each plot produced tassels and silk. Days taken to dough stage were recorded when 50 per cent of the plants has whitish yellow to yellow kernels and fingernail impression was not implanted on them. Days taken to physiological maturity was recorded when the kernel milk line disappeared and just before the kernel black layer forms at the tip of the kernels. Five cobs were randomly selected from each plot for taking observations on cob girth, cob length and number of grains per cob. Total $\mathrm{N}$ content in grain and straw were determined by procedure given by Piper (1966). Protein content of grains at harvest was determined by multiplying the obtained nitrogen content with 6.25 .

\section{Results and Discussion}

\section{Growth parameter}

The periodic data in respect to number of leaves per plant, which is an indication of plant growth and development, are presented in table 2. It was observed that number of leaves per plant increased up to 60 days after sowing (DAS) and thereafter a decreasing trend was recorded at $80 \mathrm{DAS}$ and at harvest both for planting methods and nitrogen levels. Lower dry leaves were not counted after 60 DAS. Different planting methods had no 
significant effect on number of leaves per plant at all growth stages. The crop planted under zero tillage (ZT) had comparatively lesser number of leaves per plant as compared to other two planting methods (CT and BP) at all the growth stages. Application of nitrogen had a significant effect on number of leaves per plant at 20,60 as well at 80 DAS. At 20 and $60 \mathrm{DAS}$, application of $150 \mathrm{~kg} \mathrm{~N} / \mathrm{ha}$ recorded maximum number of leaves (6.2 and 12.7), which was at par with 100 (6.0 and 12.4) and $125 \mathrm{~kg} \mathrm{~N} / \mathrm{ha}$ (6.1 and 12.6) and at $80 \mathrm{DAS}, 125 \mathrm{~kg} \mathrm{~N} / \mathrm{ha}(9.8)$ and $150 \mathrm{~kg} \mathrm{~N} / \mathrm{ha}$ (10.0) was at par with each other but significantly higher than $0 \mathrm{~kg} \mathrm{~N} / \mathrm{ha}$ (8.4) and $100(9.0)$ at $5 \%$. The interaction effect on number of leaves per plant among planting methods and nitrogen levels was nonsignificant.

\section{Growth analysis}

Crop growth rate (CGR) showed an increasing trend up to 50-70 days after sowing and then decreased at 70-80 DAS (Table 3). This was due to better growth rate during the initial stage of the crop and maximum at the peak growth stage (50-70 DAS). At 30-50 DAS stages, Bed planted crop $\left(0.94 \mathrm{~g} \mathrm{~m}^{-2}\right.$ day $^{-1}$ ) showed significantly higher CGR as compared with conventional $\left(0.64 \mathrm{~g} \mathrm{~m}^{-2}\right.$ day $\left.{ }^{1}\right)$ and zero tillage $\left(0.50 \mathrm{~g} \mathrm{~m}^{-2}\right.$ day $\left.^{-1}\right)$ method at $5 \%$. CGR also showed the same trend among the different methods of planting as recorded during 50-70 DAS. It was not influenced by methods of planting during 70-80 DAS. Increased CGR in bed planted crop might be due to better plant growth. Similar increase in CGR in rainfed upland rice crop age was observed by Chauhan et al., (1999). Among various nitrogen levels CGR showed an increasing trend as nitrogen level increased from 0 to $150 \mathrm{~kg} / \mathrm{ha}$. Higher CGR during 30 50 DAS was recorded at $150 \mathrm{~kg}$ N/ha $(1.02 \mathrm{~g}$ $\mathrm{m}^{-2}$ day $\left.^{-1}\right)$, which was significantly better than $125 \mathrm{~kg} \mathrm{~N} / \mathrm{ha}\left(0.80 \mathrm{~g} \mathrm{~m}^{-2} \mathrm{day}^{-1}\right), 100 \mathrm{~kg} \mathrm{~N} / \mathrm{ha}$ $\left(0.52 \mathrm{~g} \mathrm{~m}^{-2}\right.$ day $\left.^{-1}\right)$ and control $\left(0.42 \mathrm{~g} \mathrm{~m}^{-2}\right.$ day $\left.{ }^{1}\right)$. During 50-70 DAS, it was recorded highest at $150 \mathrm{~kg} \mathrm{~N} / \mathrm{ha}\left(10.7 \mathrm{~g} \mathrm{~m}^{-2} \mathrm{day}^{-1}\right)$, which was statistically at par with $125 \mathrm{~kg} \mathrm{~N} / \mathrm{ha}$ (10.6) but significantly superior to other levels of nitrogen at 5\% significance level. However, CGR did not varied significantly with nitrogen levels at 70-80 DAS.

Like CGR, relative growth rate (RGR) also showed an increasing trend up to 50-70 DAS, but during 70-80 DAS it showed decreasing trend (Table 4). During 30-50 DAS, planting methods had significant effect on RGR. At this stage bed planting method showed significantly higher RGR (0.024 $\mathrm{g} \mathrm{g}^{-1}$ day $\left.^{-1}\right)$ than other methods of planting. However, significantly lower RGR (0.014 $\mathrm{g} \mathrm{g}^{-1}$ day $\left.^{-1}\right)$ was recorded in zero tillage method as compared to other methods of planting. At 50-70 and 70-80 DAS, it did not vary with different planting methods. However, bed planting method recorded maximum value of RGR which was comparatively higher than conventional and zero tillage method but the differences were observed non-significant. Various nitrogen levels showed significant effect on RGR at 30-50, 50-70 and 70-80 DAS stages. The highest RGR was recorded with the application of $150 \mathrm{~kg} \mathrm{~N} / \mathrm{ha}$, which was significantly higher than that recorded at other nitrogen levels at 30-50 and 70-80 DAS but remained at par with $125 \mathrm{~kg}$ N/ha at $50-70$ DAS.

The data with respect to Net Assimilation rate (NAR) are presented in table 5. NAR increased with age up to 50-70 DAS and declined thereafter. Net assimilation rate did not vary with different methods of planting. It was at par with each other during 30-50, 5070 and 70-80 DAS. Although Bed planted crop recorded comparatively higher NAR than other methods of planting. During initial growing period i.e. 30-50 DAS, NAR was maximum with application of $150 \mathrm{~kg} \mathrm{~N} / \mathrm{ha}$ 
which was at par with $125 \mathrm{~kg} \mathrm{~N} / \mathrm{ha}$ but significantly more than that obtained with the application of 0 and $100 \mathrm{~kg} \mathrm{~N} / \mathrm{ha}$. At 50-70 and 70-80 DAS, net assimilation rate did not vary with different nitrogen levels. Result could be explained on the basis of that $\mathrm{N}$ supplies affecting the growth and assimilation rate in plant mainly by altering the size of the photosynthetic apparatus i.e. leaf area reported by McCollum (1978). Akram et al., (2010) reported that application of nitrogen at level higher than recommended significantly improved NAR up to $225 \mathrm{~kg} \mathrm{~N} / \mathrm{ha}$.

\section{Phenological parameters}

The number of days taken for 50 per cent tasseling did not vary significantly with the methods of planting. Among the planting methods, bed planted plants recorded early anthesis than conventional and zero tillage planting (Table 6). The bed planted crop took 52.1 days followed by conventional tillage (52.6 days) and zero tillage (53 days) for anthesis. No significant effects of $\mathrm{N}$ levels were observed on the days taken to 50 per cent tasseling in fodder maize. The crop applied with $150 \mathrm{~kg} \mathrm{~N} / \mathrm{ha}$ took less days to 50 $\%$ tasseling stages i.e. (52 DAS) followed by $125 \mathrm{~kg} \mathrm{~N} / \mathrm{ha}(52.3 \mathrm{DAS})$ and $100 \mathrm{~kg} \mathrm{~N} / \mathrm{ha}$ (52.6 DAS). However, under the control treatment plants took more days to attain 50 $\%$ tasseling. Reduction in number of days taken for anthesis with increasing levels of $\mathrm{N}$ may be attributed to higher LAI that resulted in healthy plants and influenced tasseling. The interaction effect was found to be nonsignificant. The trend in number of days taken to 50 per cent silking under different planting methods was similar days taken to 50 per cent tasseling (Table 6). Time taken for silking period was 57.8 days in bed planted crop followed by conventional tillage (58.1 days) and zero tillage planted maize 58.6 days. As regarding effect of different nitrogen levels maximum number of days to silking was recorded under control treatment (59.3 DAS) followed by $125 \mathrm{~kg}$ N/ha (58.2 DAS), $100 \mathrm{~kg}$ $\mathrm{N} / \mathrm{ha}(57.5 \mathrm{DAS})$ and $150 \mathrm{~kg} \mathrm{~N} / \mathrm{ha}(57.5$ DAS) applied to the crop plants.

Data regarding on the days taken to the dough stage of grains are presented in table 6 . Planting methods significantly influenced the days taken to reach dough stage in maize. Bed planting method took significantly lesser no. of days to reach dough stage compared to conventional and zero tillage method. Bed planted crop attained this stage after 77.0 days, whereas, conventional and zero tillage attained this stage in 83.1 and 88.0 days, respectively. Different levels of nitrogen had no effect on the days taken to reach dough stage. The crop fertilized with $150 \mathrm{~kg} \mathrm{~N} / \mathrm{ha}$ (83.5 DAS) reached dough stage 2 or 3 days late as compared to $125 \mathrm{~kg} \mathrm{~N} / \mathrm{ha}$ (83.3 DAS), $100 \mathrm{~kg} \mathrm{~N} / \mathrm{ha}$ (83.1 DAS) and control (81.7 DAS). All interaction effects due to various treatments were non-significant.

The data with respect to days taken to physiological maturity are presented in table 7. The crop reached physiological maturity stage earlier in bed planting (95.4 DAS) as compared to conventional (96.7 DAS) and zero tillage (97.7 DAS) method of sowing. This was due to better crop growth and early completion of stages of development in bed planted crop. The crop receiving $150 \mathrm{~kg} \mathrm{~N} / \mathrm{ha}$ took 97.6 days to reach physiological maturity, which was significantly at par with $125 \mathrm{~kg} \mathrm{~N} /$ ha (97.1) but significantly more than $100 \mathrm{~kg} \mathrm{~N} / \mathrm{ha}$ (95.8) and control. It is clear from the data that higher nitrogen level delays the physiological maturity of the crop as compared to lower nitrogen level.

\section{Yield attributes}

The data regarding the number of cobs per plant are presented in table 7. Comparatively higher numbers of cobs per plant (1.3) were 
recorded in bed planting method as compared to conventional tillage (1.1) and zero tillage (1.0). However, the results were nonsignificant. These results are also confirmed by Jafer et al., (1998) who reported that in summer maize number of cobs per plant was not significantly affected by planting methods. Nitrogen levels also did not influence number of cobs per plant and it was observed that the crop fertilized with $150 \mathrm{~kg}$ $\mathrm{N} /$ ha results comparatively higher cobs per plant (1.2) as compared to other nitrogen levels. Bakht et al., (2007) reported that maximum number of cobs per plant (0.88) was recorded in plots receiving $160 \mathrm{Kg} \mathrm{N} / \mathrm{ha}$, while minimum number of cobs per plant was noted in control plots in autumn planted maize. The interaction effects were found to be non significant.

The data presented in table 7 show that there was no significant difference in cob girth among all the planting methods. Bed planted maize showed maximum cob girth $(3.5 \mathrm{~cm})$ followed by conventional tillage $(3.4 \mathrm{~cm})$ and was least under zero tillage method $(3.3 \mathrm{~cm})$. The cob girth increased significantly with each increment in nitrogen dose. The cob girth was significantly more at $100 \mathrm{~kg} \mathrm{~N} / \mathrm{ha}$ $(3.4 \mathrm{~cm})$ as compared with $0 \mathrm{~kg} \mathrm{~N} / \mathrm{ha}(3.2$ $\mathrm{cm})$, but was at par with $125 \mathrm{~kg} \mathrm{~N} / \mathrm{ha}(3.5$ $\mathrm{cm})$. The plots applied with $150 \mathrm{~kg}$ N/ha $(3.6$ $\mathrm{cm})$ showed significantly higher cob girth as compared to those applied with 0 and $100 \mathrm{~kg}$ $\mathrm{N} / \mathrm{ha}$ but was at par under $125 \mathrm{~kg} \mathrm{~N} / \mathrm{ha}$. Pandey et al., (2000) have also reported that $\mathrm{N}$ application favorably improved the cob girth and ultimate yield of maize crop. However, interaction between different planting methods and nitrogen levels did not affect the cob girth significantly.

The data on number of grains per cob presented in table 7 reveals that methods of planting had no significant effect on number of grains per cob. However, higher numbers of grains per cob (258.5) were recorded in bed planted crop as compared to other methods. Monneveux et al., (2006) also reported less number of grains per cob in maize in zero tillage method as compared to conventional tillage method.

Number of grains per cob remained statistically at par when $\mathrm{N}$ level was increased from 100 to $150 \mathrm{~kg}$ /ha but were significantly higher than control (187.8). However, the maximum number of grains per cob (261.1) was recorded with the application of $150 \mathrm{~kg}$ $\mathrm{N} / \mathrm{ha}$. The increase in number of grains with increased nitrogen levels was also reported by Edalat et al., (2009). Maqsood et al., (2001), found higher number of grains per cob (299.94) at $120 \mathrm{~kg} \mathrm{~N} / \mathrm{ha}$ and concluded that high levels of $\mathrm{N}$ probably increased the size of individual ear and thus number of grains per cob also increased.

Yielding ability is one of the most important quantitative characters in a crop and it depends upon the development of plant characters viz., no. of leaves, leaf area etc, which in turn result into higher growth parameters viz., relative growth rate, crop growth rate and leaf area index. Grain yield was not significantly affected by the planting methods (Table 7). Maximum grain yield (48.0 q/ha) was recorded with bed planted method, which was 7.0 per cent higher as compared to conventional tillage and 7.5 per cent higher as compared to zero tillage. Whereas, conventional tillage produced 0.4 per cent higher grain yield as compared to zero tillage. Slightly higher grain yield under bed planting might be due to better crop growth and comparatively higher yield contributing attributes as compared to other sowing methods. Bed planting might have created favorable conditions for the growth and development of the crop through the reduced loss of nutrients through leaching by avoiding direct contact of water with nutrients 
present near the base and thus helped in retention of nutrients in the root zone. Aggarwal et al., (2000) showed slightly higher maize yield on raised bed than on flat sowing. Singh et al., (2000) also observed a significant increase in grain yield in winter maize at high $\mathrm{N}$ levels. Grain yield of maize is a function of yield attributes, which are favorably influenced by $\mathrm{N}$ application. The higher yield with increase in nitrogen doses could be supported probably by higher levels of chlorophyll in august sown hybrid maize. since nitrogen is an important constituent of chlorophyll as reported by Singh (2010). Thus, the photosynthesis might have taken place at an efficient level there by producing photosynthates for higher growth and development as indicated by number of leaves per plant (Table 2). When the plant shifted from vegetative to reproductive phase higher amount of source resulted in better development of sink size as indicated by cob length and cob girth (Table 7).

All these factors helped to fill the sink to the capacity which resulted in higher grain yield. Dar et al., (2014), reported that with the application of $\mathrm{N}$ up to $120 \mathrm{~kg} \mathrm{~N} / \mathrm{ha}$ significantly improved growth and yield attributes of baby corn. Karasu A (2012) reported that when the nitrogen levels increased, grain yield also significantly increased up to $300 \mathrm{~kg} \mathrm{~N} / \mathrm{ha}$. The highest grain yield $(13323 \mathrm{~kg} / \mathrm{ha})$ was obtained from $300 \mathrm{~kg} \mathrm{~N} / \mathrm{ha}$ nitrogen doze, and the lowest yield $(9805 \mathrm{~kg} / \mathrm{ha})$ was produced the control plant (0 kg N /ha).

\section{Quality studies}

\section{Nitrogen content in grains and stover}

Perusal of data given in table 8 regarding nitrogen content (per cent) in grains and stover of maize planted in relation to various planting methods and nitrogen levels reveal that nitrogen content in grains as well as stover was not influenced by different planting methods. Bed planted maize showed 1.6 per cent nitrogen content in grains and 1.4 per cent in stover which was comparatively high as compared to conventional and zero tillage methods. Among the nitrogen treatment, crop receiving $150 \mathrm{~kg} \mathrm{~N} / \mathrm{ha}$ had significantly (1.8 per cent) higher nitrogen content in grains as compared to control, but at par with $125 \mathrm{~kg} \mathrm{~N} / \mathrm{ha}$ (1.7 per cent) and 100 $\mathrm{kg} \mathrm{N} / \mathrm{ha}(1.6$ per cent). Similarly, nitrogen content in stover was significantly higher in $150 \mathrm{~kg} \mathrm{~N} / \mathrm{ha}$ (1.7 per cent), $125 \mathrm{~kg} \mathrm{~N} / \mathrm{ha}(1.6$ per cent), $100 \mathrm{~kg} \mathrm{~N} / \mathrm{ha}$ (1.4 per cent) as compared to control ( 0.6 per cent). Mahdi et al., (2012) reported that application of $\mathrm{N} @$ $120 \mathrm{~kg} / \mathrm{ha}$ has resulted significantly higher nitrogen content $(1.55 \%)$ as compared to rest of the nitrogen levels.

Interaction between planting methods and nitrogen levels was found to be nonsignificant.

The data regarding protein content in grains is given in table 8 , which indicates that protein content in maize grain was not significantly influenced by different planting methods. However bed planted crop (8.7 per cent) showed maximum protein content as compared to other planting methods.

Protein content was, however, significantly increased by nitrogen application. With each increment dose of nitrogen from control to $150 \mathrm{~kg} \mathrm{~N} / \mathrm{ha}$, the protein content in maize grain increased. The protein content with application of $150 \mathrm{~kg} \mathrm{~N} / \mathrm{ha}$ (11 per cent) was significantly higher than the lower dose of $\mathrm{N}$ and was more than double as compared to control (5.6). This tendency of increased protein content in grain may be attributed to higher nitrogen uptake by the plants in plots receiving more nitrogen and higher translocation of photosynthates to the grains. 
Table.1 Weekly meteorological data recorded at Ludhiana during the crop season (20 June to 26 September 2012)

\begin{tabular}{|c|c|c|c|c|c|c|c|c|}
\hline \multirow[t]{2}{*}{$\begin{array}{l}\text { Meteorological } \\
\text { Week }\end{array}$} & \multicolumn{3}{|c|}{$\begin{array}{c}\text { Air temperature } \\
\left({ }^{\circ} \mathrm{c}\right)\end{array}$} & \multicolumn{3}{|c|}{ Relative humidity (\%) } & \multirow[t]{2}{*}{$\begin{array}{c}\text { Rainfall } \\
(\mathrm{mm})\end{array}$} & \multirow[t]{2}{*}{$\begin{array}{c}\text { Evaporation } \\
(\mathrm{mm})\end{array}$} \\
\hline & Max. & Min. & Mean & Morning & Evening & Mean & & \\
\hline 25 & 40.8 & 29.3 & 35.0 & 56.4 & 33.4 & 44.9 & 0.3 & 10.1 \\
\hline 26 & 39.4 & 27.9 & 33.6 & 63.1 & 39.5 & 43.9 & 3.4 & 11.9 \\
\hline 27 & 36.9 & 28.6 & 32.7 & 70.0 & 53.0 & 61.5 & 1.4 & 9.8 \\
\hline 28 & 35.0 & 27.6 & 31.3 & 78.7 & 56.0 & 67.4 & 1.5 & 6.4 \\
\hline 29 & 36.4 & 27.8 & 32.1 & 72.5 & 52.1 & 62.4 & 0.2 & 6.7 \\
\hline 30 & 35.0 & 28.0 & 31.5 & 82.1 & 67.5 & 64.4 & 6.4 & 5.8 \\
\hline 31 & 33.8 & 27.4 & 30.6 & 80.0 & 68.0 & 74.0 & 4.9 & 8.0 \\
\hline 32 & 34.0 & 27.1 & 30.5 & 88.0 & 72.4 & 80.2 & 2.5 & 3.9 \\
\hline 33 & 33.8 & 26.8 & 30.3 & 86.4 & 72.7 & 79.6 & 8.8 & 3.9 \\
\hline 34 & 31.5 & 25.9 & 28.7 & 84.0 & 79.9 & 84.4 & 6.1 & 3.3 \\
\hline 35 & 33.0 & 26.0 & 29.5 & 90.6 & 69.3 & 68.2 & 5.8 & 3.2 \\
\hline 36 & \begin{tabular}{|l|}
32.8 \\
\end{tabular} & 26.3 & 29.5 & 81.6 & 69.0 & 75.3 & 2.7 & 4.0 \\
\hline 37 & 33.9 & 25.5 & 29.7 & 89.0 & 63.7 & 76.4 & 13.3 & 3.8 \\
\hline 38 & 31.0 & 22.5 & 26.7 & 93.0 & 68.1 & 80.6 & 3.9 & 3.3 \\
\hline 39 & 33.0 & 20.7 & 26.6 & 93.7 & 48.4 & 60.7 & 0.0 & 4.1 \\
\hline
\end{tabular}

(Source: Meteorological data recorded at PAU meteorological observatory, Ludhiana)

Table.2 Effect of planting methods and nitrogen levels on the number of leaves per plant at different stages of fodder maize

\begin{tabular}{|c|c|c|c|c|c|}
\hline \multirow{2}{*}{ Treatment } & \multicolumn{5}{|c|}{ Number of leaves per plant } \\
\cline { 2 - 6 } & $\mathbf{2 0}$ DAS & 40 DAS & 60 DAS & $\mathbf{8 0}$ DAS & At harvest \\
\hline Planting method \\
\hline ZT & 5.8 & 9.0 & 12.0 & 9.1 & 6.0 \\
\hline CT & 6.0 & 9.5 & 12.1 & 9.3 & 6.7 \\
\hline BP & 6.2 & 9.7 & 12.2 & 9.4 & 6.7 \\
\hline CD (p=0.05) & NS & NS & NS & NS & NS \\
\hline Nitrogen level (kg/h) & 5.7 & 8.8 & 10.8 & 8.4 & 6.2 \\
\hline 0 & 6.0 & 9.4 & 12.4 & 9.0 & 6.3 \\
\hline 100 & 6.1 & 9.6 & 12.6 & 9.8 & 6.6 \\
\hline 125 & 6.2 & 9.7 & 12.7 & 10.0 & 6.7 \\
\hline 150 & 0.3 & NS & 0.6 & 0.9 & NS \\
\hline CD (p=0.05) & NS & NS & NS & NS & NS \\
\hline $\begin{array}{l}\text { Interaction M X } \\
\text { N }\end{array}$ & & & & \\
\hline
\end{tabular}

DAS -Days after Sowing; M- Planting methods; N- Nitrogen levels 
Table.3 Effect of planting methods and nitrogen levels on crop growth rate at different stages of fodder maize

\begin{tabular}{|c|c|c|c|}
\hline \multirow{2}{*}{ Treatment } & \multicolumn{3}{|c|}{ Crop growth rate $\left(\mathrm{g} \mathrm{m}^{-2}\right.$ day $\left.^{-1}\right)$} \\
\hline & 30-50 DAS & 50-70 DAS & 70-80 DAS \\
\hline \multicolumn{4}{|l|}{ Planting method } \\
\hline ZT & 0.50 & 8.9 & 3.1 \\
\hline CT & 0.64 & 8.7 & 3.3 \\
\hline BP & 0.94 & 9.7 & 4.3 \\
\hline $\mathrm{CD}(\mathrm{p}=0.05)$ & 0.03 & 0.70 & NS \\
\hline \multicolumn{4}{|c|}{ Nitrogen level (kg/ha) } \\
\hline 0 & 0.42 & 5.7 & 2.3 \\
\hline 100 & 0.52 & 9.4 & 2.9 \\
\hline 125 & 0.80 & 10.6 & 4.1 \\
\hline 150 & 1.02 & 10.7 & 5.0 \\
\hline $\mathrm{CD}(\mathrm{p}=0.05)$ & 0.12 & 0.7 & NS \\
\hline $\begin{array}{c}\text { Interaction } \mathrm{M} \mathrm{X} \\
\mathrm{N}\end{array}$ & 0.14 & NS & NS \\
\hline
\end{tabular}

DAS -Days after Sowing; $\quad$ M- Planting methods; N- Nitrogen levels

Table.4 Effect of planting methods and nitrogen levels on relative growth rate at different stages of fodder maize

\begin{tabular}{|c|c|c|c|}
\hline \multirow{2}{*}{ Treatment } & \multicolumn{3}{|c|}{ Relative growth rate $\left(\mathbf{g ~ g}^{-1}\right.$ day $\left.^{-1}\right)$} \\
\cline { 2 - 4 } & 30-50 DAS & $\mathbf{5 0 - 7 0}$ DAS & $\mathbf{7 0 - 8 0}$ DAS \\
\hline Planting method & \multicolumn{3}{|c|}{} \\
\hline ZT & 0.014 & 0.084 & 0.013 \\
\hline CT & 0.020 & 0.084 & 0.014 \\
\hline BP & 0.024 & 0.088 & NS \\
\hline CD (p=0.05) & 0.003 & NS & 0.018 \\
\hline Nitrogen level (kg/ha) & 0.012 & 0.072 & 0.019 \\
\hline 0 & 0.014 & 0.082 & 0.020 \\
\hline 100 & 0.023 & 0.090 & 0.087 \\
\hline 125 & 0.029 & 0.092 & 0.01 \\
\hline 150 & 0.004 & 0.005 & NS \\
\hline CD (p=0.05) & 0.003 & NS & \\
\hline Interaction M X & N &
\end{tabular}

DAS -Days after Sowing; $\quad$ M- Planting methods; N- Nitrogen level 
Table.5 Effect of planting methods and nitrogen levels on net assimilation rate at different stages of fodder maize

\begin{tabular}{|c|c|c|c|}
\hline \multirow{2}{*}{ Treatment } & \multicolumn{3}{|c|}{ Net assimilation rate $\left(\mathbf{g ~ g}^{-1}\right.$ day $\left.^{-1}\right)$} \\
\cline { 2 - 4 } & $\mathbf{3 0 - 5 0}$ DAS & $\mathbf{5 0 - 7 0}$ DAS & $\mathbf{7 0 - 8 0}$ DAS \\
\hline Planting method & \multicolumn{3}{|}{} \\
\hline ZT & 0.002 & 0.046 & 0.012 \\
\hline CT & 0.005 & 0.047 & 0.014 \\
\hline BP & 0.006 & 0.048 & 0.018 \\
\hline CD (p=0.05) & NS & NS & NS \\
\hline Nitrogen level (kg/ha) & 0.002 & 0.043 & 0.011 \\
\hline 0 & 0.003 & 0.047 & 0.013 \\
\hline 100 & 0.005 & 0.048 & 0.016 \\
\hline 125 & 0.006 & 0.050 & 0.018 \\
\hline 150 & 0.001 & NS & NS \\
\hline CD (p=0.05) & 0.001 & NS & NS \\
\hline Interaction M x N &
\end{tabular}

DAS -Days after Sowing; M- Planting methods; N- Nitrogen levels

Table.6 Effect of planting methods and nitrogen levels on the phenological stages of fodder maize

\begin{tabular}{|c|c|c|c|c|}
\hline \multirow[b]{2}{*}{ Treatment } & \multicolumn{4}{|c|}{ Days to sowing } \\
\hline & $50 \%$ tasseling & 50\% silking & Dough stage & $\begin{array}{l}\text { Physiological } \\
\text { maturity }\end{array}$ \\
\hline \multicolumn{5}{|l|}{ Planting method } \\
\hline ZT & 53.0 & 58.6 & 88.0 & 97.7 \\
\hline $\mathrm{CT}$ & 52.6 & 58.1 & 83.1 & 96.7 \\
\hline BP & 52.1 & 57.8 & 77.0 & 95.4 \\
\hline $\mathrm{CD}(\mathrm{p}=0.05)$ & NS & NS & 1.1 & NS \\
\hline \multicolumn{5}{|c|}{ Nitrogen level (kg/ha) } \\
\hline 0 & 53.4 & 59.3 & 81.7 & 95.8 \\
\hline 100 & 52.6 & 58.2 & 83.1 & 95.8 \\
\hline 125 & 52.3 & 57.7 & 83.3 & 97.1 \\
\hline 150 & 52.0 & 57.5 & 83.5 & 97.6 \\
\hline $\mathrm{CD}(\mathrm{p}=0.05)$ & NS & NS & NS & 1.26 \\
\hline Interaction $\mathrm{M} \times \mathrm{N}$ & NS & NS & NS & NS \\
\hline
\end{tabular}

M- Planting methods; N- Nitrogen levels 
Table.7 Effect of planting methods and nitrogen levels on yield attributes of fodder maize

\begin{tabular}{|c|c|c|c|c|c|}
\hline Treatment & $\begin{array}{c}\text { Cob } \\
\text { length } \\
(\mathrm{cm})\end{array}$ & $\begin{array}{l}\text { Cob girth } \\
\text { (cm) }\end{array}$ & $\begin{array}{c}\text { Number } \\
\text { of cobs } \\
\text { per plant }\end{array}$ & $\begin{array}{c}\text { Number of } \\
\text { grains per } \\
\text { cob }\end{array}$ & $\begin{array}{c}\text { Grain } \\
\text { yield } \\
\text { (q/ha) }\end{array}$ \\
\hline \multicolumn{6}{|l|}{ Planting method } \\
\hline ZT & 8.7 & 3.3 & 1.0 & 231.0 & 44.4 \\
\hline CT & 11.1 & 3.4 & 1.1 & 246.5 & 44.6 \\
\hline $\mathrm{BP}$ & 12.7 & 3.5 & 1.3 & 258.5 & 48.0 \\
\hline $\mathrm{CD}(\mathrm{p}=0.05)$ & 0.7 & NS & NS & NS & NS \\
\hline \multicolumn{6}{|c|}{ Nitrogen level $(\mathrm{kg} / \mathrm{ha})$} \\
\hline 0 & 6.0 & 3.2 & 1.0 & 187.8 & 144.9 \\
\hline 100 & 9.8 & 3.4 & 1.1 & 257.8 & 171.8 \\
\hline 125 & 13.5 & 3.5 & 1.1 & 261.1 & 207.4 \\
\hline 150 & 14.0 & 3.6 & 1.2 & 274.8 & 213.7 \\
\hline $\mathrm{CD}(\mathrm{p}=0.05)$ & 1.2 & 0.1 & NS & 47.6 & 20.0 \\
\hline $\begin{array}{c}\text { Interaction } \mathrm{M} X \\
\mathrm{~N}\end{array}$ & NS & NS & NS & NS & 19.3 \\
\hline
\end{tabular}

M- Planting methods; N- Nitrogen level

Table.8 Effect of planting methods and nitrogen levels on nitrogen content and protein content in grains and stover of fodder maize

\begin{tabular}{|c|c|c|c|}
\hline Treatment & $\begin{array}{c}\text { Nitrogen in grains } \\
(\mathbf{\%})\end{array}$ & $\begin{array}{c}\text { Nitrogen in stover } \\
(\mathbf{\%})\end{array}$ & $\begin{array}{c}\text { Protein in grains } \\
(\mathbf{\%})\end{array}$ \\
\hline Planting method & 1.5 & 1.3 & 9.4 \\
\hline ZT & 1.5 & 1.3 & 9.4 \\
\hline CT & 1.6 & 1.4 & 10 \\
\hline BP & NS & NS & NS \\
\hline CD (p=0.05) & \multicolumn{3}{|l|}{} \\
\hline Nitrogen level (kg/ha) & 0.9 & 0.6 & 5.6 \\
\hline 0 & 1.6 & 1.4 & 10 \\
\hline 100 & 1.7 & 1.6 & 10 \\
\hline 125 & 1.8 & 1.7 & 11 \\
\hline 150 & 0.4 & 0.6 & 2.5 \\
\hline CD (p=0.05) & NS & NS & NS \\
\hline Interaction M X & N &
\end{tabular}

M- Planting methods; N- Nitrogen levels

Mahdi et al., (2012) reported that protein content and its yield in fodder maize showed significant increase with an increase in $\mathrm{N}$ level from 60 to $120 \mathrm{~kg} / \mathrm{ha}(9.69 \%)$. Interaction effect between planting methods and nitrogen levels was non-significant.
In conclusion, the results of the investigation indicated that all the planting methods like zero tillage, conventional tillage and bed planting gave nearly same grain yield. Application of $150 \mathrm{~kg} \mathrm{~N} / \mathrm{ha}$ produced higher yield attributes over 0,100 and $125 \mathrm{~kg} \mathrm{~N} / \mathrm{ha}$ 
at 5\% significance level and hence give more yield as compared to rest of the treatments. This showed that planting fodder maize with zero tillage can be produced more economic benefits by skipping the tillage operation at the time of planting as all other growth and yield parameters are at par with each other.

\section{Acknowledgements}

The authors are thankful to the Head Department of Agronomy, Punjab Agricultural University, Ludhiana for the financial assistance for carrying out the research.

\section{References}

Aggarwal, P., Garg, R.N., Singh, A.K., Singh, S., Yadav, A.L. and Sharma, A.M. 2000. Assessment of bed planting system in maize for enhancing water use efficiency. In Proceeding International Conference on Managing Natural Resources for Sustainable Agricultural Production in $21^{\text {st }}$ century. February 14-18 at IARI Indian Society Soil Sciences New Delhi, India, 175176.

Akram, M., Ashraf, M.Y., Waraich, E.A., Hussain M., N. Hussainand Mallahi A.R. 2010. Performance of autumn planted maize (Zea mays L.) hybrids at various nitrogen levels under salt affected soils. Soil Environ., 29: 23-32.

Bakht, J., Siddique, M.F., Shafi, M., Akbar, H., Tariq, M., Khan, N., Zubair, M. and Yousef, M. 2007. Effect of planting methods and nitrogen levelson the yield and yield components of maize. Sarhad. J. Agric., 23: 553-59.

Brady, N.C. and Weil, R.R. 2014. Soil Colloids: Seat of Soil Chemical and Physical Acidity. In: Brady N.C., Weil R.R., editors. The Nature and Properties of Soils. Pearson Education Inc.; Upper
Saddle River, NJ, USA: 2008. pp. 311358.

Chaudhary, D.P., Kumar, A.S., Sapna., Mandhania, Srivastava, P. and Kumar, R.S. 2012. Maize As Fodder? An alternative approach, Directorate of Maize Research, Pusa Campus, New Delhi -110 012, Technical Bull., pp. 32.

Chauhan, J.S., Singh, C.V. and Singh, R.K. 1999. Interrelationship of growth parameters in rainfed upland rice (Oryza sativa L.. Indian. J. Pl. Physiol., 4: 43-45.

Cheng-Wei, Liu., Yu, Sung., Bo-Ching, Chen., and Hung-Yu, Lai. 2014. Effects of Nitrogen Fertilizers on the Growth and Nitrate Content of Lettuce (Lactuca sativa L.. Int. J. Environ. Res. Public. Health, 11: 4427-4440.

Dar, E.A., Harika, A.S., Datta, A. and Jat, H.S. 2014. Growth, yield and economic returns from the dual purpose baby corn (Zea mays) under different planting geometry and nitrogen levels. Indian. J. Agron., 59: 468-470.

Edalat, M., Kazemeini, S.A., Bijanzadeh, E. and Naderi, R. 2009. Impact of irrigation and nitrogen on determining the contribution of yield components and morphological traits on corn kernel yield. J. Agron., 8: 84-88.

Hirel, B., Bertin, P., Quillere, I., Bourdoncle, W., Attagnant, C., Delay, C., Gouy, A., Cadiou, S., Retaillau, C., Falque, M. and Gallis, A. 2001. Towards a better understanding of the genetic and physiological basis for nitrogen use efficiency in maize. Pl. Physiol., 125: 1258-70.

Hunt. 1989. Basic growth analysis: Plant Growth Analysis for beginners. Unwin layman $(\mathrm{Pb})$, London.

Jafar, M.N., Alsssssi, K., Hussain, H. and Ayub, M. 1988. Effect of planting pattern on growth and yield of summer maize. J. Agric. Res., 25: 41-45. 
Karasu, A. 2012. Effect of nitrogen levels on grain yield and some attributes of some hybrid maize cultivars (Zea mays indentata Sturt.) grown for silage as second crop. Bulg. J. Agric. Sci., 18: 4248.

Mahdi, S., Hasan. B. and Singh, L. 2012. Influence of seed rate, nitrogen and zinc on fodder maize (Zea mays) in temperate conditions of western Himalayas. Indian. J. Agron., 57: 85-88.

Maqsood, M., Amanat, A.A., Iqbal, I. and Hussain, M.I. 2001. Effect of variable rates of nitrogen and phosphorus on growth and yield of maize (Golden. Biol. Sci., 1:19-20.

McCollum, R.E. 1978. Analysis of potato growth under different $\mathrm{P}$ regimes. II. Time by P- status interaction for growth and leaf efficiency. Agron. J., 70:58-67.

Monneveux, E.Q., Sanchez, C. and Lopez, J.C. 2006. Effect of zero tillage and residue conservation on continuous maize cropping in a subtropical environment (Mexico. Plant Soil., 279: 95-105.

Pandey, A.K., Parakash, V., Singh, R. D. and Mani, V.P. 2000. Response of maize varieties to nitrogen levels and sulphydryl compounds. Crop, Res., 9: 28-33.

Piper, C.S. 1966. Soil and Plant Analysis. Pp 223-37, Hans publishers, Bombay.

Sayre, K.D. 2003. Raised- bed cultivation. In: Rattan Lal (ed.) Encyclopedia of Soil Sci., pp 1-4.

Simes, A.L., Schepers, J.S., Olson, R.A. and Power, J.F. 1998. Irrigated corn yield and nitrogen accumulation response in a comparison of no-till and conventional till: Tillage and surface-residue variables. Agron. J., 90: 630-37.

Singh, D.P., Rana, N.S. and Singh, R.P. 2000. Dry matter production and nutrient uptake in winter maize (Zea mays L.) based intercropping system under different levels of nitrogen. Indian. J. Agron., 45: 676-80.

Singh, G. 2010. Irrigation and nitrogen needs of august sown hybrid maize. M.Sc. Thesis, Department of Agronomy, Punjab Agricultural University, Ludhiana, Punjab.

Singh, S. 1984. Studies on some agronomic aspects of winter maize (Zea mays L.) Ph.D. Dissertation, Punjab Agricultural University, Ludhiana.

\section{How to cite this article:}

Rupinder Kaur Jassal, J.S. Kang, Harmeet Singh and Thakar Singh. 2017. Growth, Phenology and Seed Yield of Fodder Maize in Relation to Different Planting Methods and Nitrogen Levels. Int.J.Curr.Microbiol.App.Sci. 6(4): 1723-1735.

doi: https://doi.org/10.20546/ijcmas.2017.604.207 